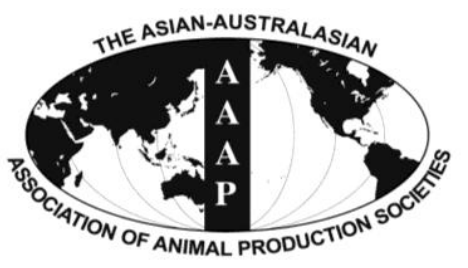

Asian Australas. J. Anim. Sci.

Vol. 26, No. 9 : 1313-1319 September 2013

http://dx.doi.org/10.5713/ajas.2012.12700

www.ajas.info

pISSN 1011-2367 elSSN 1976-5517

\title{
Effects of Low Level Water-soluble Pentosans, Alkaline-extractable Pentosans, and Xylanase on the Growth and Development of Broiler Chicks
}

\author{
Q. K. Sheng ${ }^{1,2, *}$, L. Q. Yang ${ }^{3}$, H. B. Zhao ${ }^{1,2}$, X. L. Wang ${ }^{1,2}$, and K. Wang ${ }^{1}$ \\ ${ }^{1}$ Institute of Animal Science and Veterinary Medicine, \\ Shandong Provincial Academy of Agricultural Sciences, Jinan, 250100, China
}

\begin{abstract}
This study investigated the effects of low levels of water-soluble pentosans (WSP), alkaline-extractable pentosans (AEP), and xylanase on the growth and organ development of broiler chicks. Three hundred and fifty 1-d-old female broiler chicks were randomly allocated into seven experimental groups of five pen replicates, with ten chicks per replicate. The control group consumed a corn-soybean meal-based diet. Six dietary treatment groups consumed the basal diet supplemented with one of the following: WSP at 50 $\mathrm{mg} / \mathrm{kg}$ (WSP50) or $100 \mathrm{mg} / \mathrm{kg}$ (WSP100); AEP at $50 \mathrm{mg} / \mathrm{kg}$ (AEP50) or $100 \mathrm{mg} / \mathrm{kg}$ (AEP100); or xylanase at $3 \mathrm{mg} / \mathrm{kg}$ (Xase3) or 6 $\mathrm{mg} / \mathrm{kg}$ (Xase6). Data including the body weight, digestive organ weights, gut length, rectal digesta viscosity, and gut microflora and $\mathrm{pH}$ were collected on d 5, 10, and 15. When compared to the control group, WSP50 promoted body weight gain and organ growth throughout the study, calculated as 3-d averages $(\mathrm{p}<0.05)$. WSP100 increased weight gain and enhanced organ development (proventriculus, gizzard, and gut) on $\mathrm{d} 10(\mathrm{p}<0.05)$, but the 3 -d averages were not different from the control group except for the weight of gizzard. Both Xase 3 and Xase6 increased the 3-d average weight gain and the growth of the gizzard ( $<<0.05)$. WSP50 increased the digesta viscosity compared to Xase 3 on $\mathrm{d} 10$ and 15 ( $\mathrm{p}<0.05)$. WSP50, Xase3, and Xase6 increased the concentration of Lactobacillus in the rectum when compared to the control group ( $\mathrm{p}<0.05$ ), but only Xase3 lowered the digesta $\mathrm{pH}$ in the ileum and cecum on $\mathrm{d} 10$ and 15 . AEP had minimal influence on the growth and organ development of broilers. The results showed that low levels of WSP, AEP, and xylanase had different effects and underlying mechanisms on the growth and organ development of broiler chicks. WSP50 could increase the growth performance of broilers fed a corn-soybean meal-based diet. (Key Words: Pentosan, Xylanase, Broiler, Organ, Growth)
\end{abstract}

\section{INTRODUCTION}

Pentosans, also known as arabinoxylans, are the main components of the non-starch polysaccharides in grains. They are also important polysaccharide components in the cell walls of grains. Pentosans are used as thickeners and humectants in additives for beverages, condiments, dairy products, candy, and other foods (Izydorczyk et al., 1995). As dietary fibers, pentosans play important roles in increasing intestinal motility (Shinnick et al., 1991; Topping, 2007; François et al., 2012), reducing blood sugar (Lu et al.,

\footnotetext{
* Corresponding Author: Q. K. Sheng. Tel: +86-531-88622516, Fax: +86-531-88622516, E-mail: shengqingkai71@163.com

${ }^{2}$ Shandong Provincial Key Laboratory of Animal Disease Control and Breeding, Jinan, 250100, China.

${ }^{3}$ Shandong Provincial Si Wei Chemical Safety Evaluation Center, Jinan, 250014, China.

Submitted Dec. 17, 2012; Accepted Mar. 30, 2013; Revised Jun. 3, 2013
}

2000a,b), lowering blood pressure (Anderson et al., 1994; Topping, 2007), improving immunity (Ghoneum et al., 2000; Hee-Jeong et al., 2012), and preventing colon cancer (Reddy et al., 2000). Pentosan polysulfide sodium is also effective in treating urethritis (Duthie et al., 2012). Based on their solubility, pentosans are classified as water-soluble pentosans (WSP) and water insoluble pentosans (WIP). The majority of WIP can be extracted with alkaline solutions, and are referred to as alkaline-extractable pentosans (AEP). It is not fully understood whether the functions of WSP are the same as those of AEP or pentosan mixtures.

In the feed industry, non-starch polysaccharides, such as pentosans and $\beta$-glucan, are often considered anti-nutritive factors in animal diets, especially in diets that are wheatbased. Based on data from early studies, it has been widely accepted that high viscous non-starch polysaccharides in wheat diets increase digesta viscosity and reduce the digestion and absorption of nutrients (Antoniou et al., 1981; 
Choct et al., 1990). Accordingly, xylanase or a combination of enzymes is often added to wheat feed to reduce the antinutritive effect of non-starch polysaccharide pentosans (Boguhn et al., 2007; Kalmendal et al., 2012). However, recent studies have reported that pentosans did not affect nutrient digestion and absorption, but displayed the beneficial effects of prebiotics (Kabel et al., 2002; Courtin et al., 2008; Broekaert et al., 2011; Maki et al., 2012). Pentosans are big molecules with complicated spatial structures. It is not yet clear how their physiological functions and anti-nutritive effects are related to their structures and dosage. In a previous study (Choct et al., 1990) in which the anti-nutritive effect of wheat pentosans was reported, the minimal levels of WSP and WIP added to a sorghum based diet were $4.8 \mathrm{~g} / \mathrm{kg}$ dry matter (DM) and $3.5 \mathrm{~g} / \mathrm{kg} \mathrm{DM}$, respectively. Some oligosaccharides, such as $\beta$-glucan and mannan oligosaccharide, have exhibited physiological functions at low levels (Shashidhara et al., 2003; Sohail et al., 2010; Gu et al., 2011). The present study investigated the effects of low levels of WSP and AEP supplementation (50 and $100 \mathrm{mg} / \mathrm{kg}$ diet), and xylanase supplementation ( 3 and $6 \mathrm{mg} / \mathrm{kg}$ diet) on the growth and organ development of broiler chicks fed a corn-soybean meal-based diet.

\section{MATERIALS AND METHODS}

\section{Preparation of WSP and AEP}

Wheat bran was provided by the Flour Factory of Shangdong Farm Equipment Inc. (Jinan, Shangdong, China). WSP and AEP were first extracted using thermostable $\alpha$-amylase (Wuxi Syder Bio-products Co., Ltd, Jiangsu, China) as described by Xue-Ling et al. (2008). Thereafter, the pentosan and protein content of the extract were analyzed using the phlogoglucinol reaction. The amounts of pentosans and crude protein in WSP were $78.2 \%$ and $10.4 \%$, respectively, and the amounts in AEP were $74.6 \%$ and $11.2 \%$, respectively. Xylanase was purchased from Jienuo Enzyme Co., Ltd. (Zaozhuang, Shandong, China), and the activity level of xylanase was 95819 units (U). One $\mathrm{U}$ of xylanase activity is defined as the amount of enzyme required to produce $1 \mu \mathrm{mol}$ of xylose in one minute upon hydrolysis of xylan at $\mathrm{pH} 5.0$ and $50^{\circ} \mathrm{C}$.

\section{Experimental birds and treatment diets}

Three hundred and fifty 1-d-old Ivy female broiler chicks were obtained from a local hatchery and randomly allocated to one of the seven experimental groups. Each group consisted of 5 pen replicates with 10 birds per pen. The basal diet consisted of corn-soybean meal and its composition is shown in Table 1. The WSP and AEP concentrations in the basal diet were measured to be 1.55 $\mathrm{g} / \mathrm{kg} \mathrm{DM}$ and $4.82 \mathrm{~g} / \mathrm{kg} \mathrm{DM}$ based on actual tests. The
Table 1. Composition of corn-soybean basal diet

\begin{tabular}{lc}
\hline Ingredients $(\%)$ & Proportion \\
\hline Corn meal & 65 \\
Extruded soybean meal & 30.0 \\
Peanut meal & 0.9 \\
Fish meal & 1.0 \\
Met & 0.05 \\
Lys & 0.05 \\
Premix ${ }^{1}$ & 3.0 \\
Nutrient level & Content $($ calculated $)$ \\
Metabolizable energy $(\mathrm{MJ} / \mathrm{kg})$ & 2.85 \\
Crude protein $(\%)$ & 19.5 \\
Crude fiber $(\%)$ & 2.6 \\
Lys $(\%)$ & 1.0 \\
Met+cys $(\%)$ & 0.74 \\
Ca $(\%)$ & 0.98 \\
Available phosphorus $(\%)$ & 0.41 \\
\hline
\end{tabular}

${ }^{1}$ Supplied per kilogram of diet: Fe, $100 \mathrm{mg}$; Zn, $58 \mathrm{mg} ; \mathrm{Mn}, 30 \mathrm{mg} ; \mathrm{Cu}$, $16 \mathrm{mg}$, iodine, $0.35 \mathrm{mg}$; Se, $6 \mathrm{mg}$, vitamin A, 18,000 IU; vitamin $\mathrm{D}_{3}$, 3,600 IU; vitamin $\mathrm{E}, 10.8 \mathrm{IU}$; vitamin $\mathrm{K}, 1.6 \mathrm{mg}$; vitamin $\mathrm{B}_{1}, 2.5 \mathrm{mg}$; vitamin $\mathrm{B}_{2}, 13.5 \mathrm{mg}$; vitamin $\mathrm{B}_{6}, 4.2 \mathrm{mg}$; vitamin $\mathrm{B}_{12}, 0.02 \mathrm{mg}$; niacin, $73.3 \mathrm{mg}$; pantothenic acid, $18.4 \mathrm{mg}$; folic acid, $1.2 \mathrm{mg}$; choline, $920 \mathrm{mg}$.

control group consumed the basal diet only. Six dietary treatment groups consumed the basal diet supplemented with one of the following: i) $50 \mathrm{mg} / \mathrm{kg}$ WSP (WSP50), ii) $100 \mathrm{mg} / \mathrm{kg}$ WSP (WSP100), iii) $50 \mathrm{mg} / \mathrm{kg}$ AEP (AEP50), iv) $100 \mathrm{mg} / \mathrm{kg}$ AEP (AEP100), v) $3 \mathrm{mg} / \mathrm{kg}$ xylanase (Xase 3 ), or vi) $6 \mathrm{mg} / \mathrm{kg}$ xylanase (Xase6). Each group was raised in a correspondingly single cage with 50 chicks per cage. The initial brooding temperature was $34^{\circ} \mathrm{C}$, and the temperature was gradually lowered $2^{\circ} \mathrm{C}$ each week. The ambient temperature, ventilation, and light were the same for each group. Feed and water were provided ad libitum. Standardized feeding and maintenance procedures were followed throughout the study. This study protocol was reviewed and approved by the Animal Welfare Committee of Shandong Academy of Agricultural Sciences.

\section{Assessment of growth, organ development, and gut digesta viscosity}

On d 5, 10, and 15, 10 chicks from each experimental unit were randomly selected after overnight fasting and killed by cervical dislocation. The body weight, and weights of the bursa, proventriculus, and gizzard were obtained. The length of the entire gut tract was measured. An additional 5 chicks from each experimental unit were killed and dissected to collect the rectal digesta aseptically. The digesta was then used to assess the concentrations of Lactobacillus, Streptococcus, and E. coli by plate counting. The digesta in the cecum, ileum, and rectum were gently removed and diluted at 1:30 (by weight) for $\mathrm{pH}$ measurement. The viscosity was determined in a Brookfield DV-II rotational viscometer (Brookfield), with a shear force 
Table 2. Effects of pentosan and xylanase on growth and organ development of broiler chicks

\begin{tabular}{|c|c|c|c|c|c|c|c|c|c|}
\hline & Days & Control & WSP50 & WSP100 & AEP50 & AEP100 & Xase3 & Xase6 & $\mathrm{p}$ \\
\hline \multirow{3}{*}{$\begin{array}{l}\text { Body weight } \\
\text { (g) }\end{array}$} & 5 & $54.32 \pm 4.64$ & $56.65 \pm 6.43$ & $52.58 \pm 5.63$ & $54.08 \pm 1.64$ & $54.34 \pm 4.70$ & $55.20 \pm 5.40$ & $55.13 \pm 3.38$ & 0.0513 \\
\hline & 10 & $79.98 \pm 8.35^{\mathrm{a}}$ & $89.67 \pm 7.16^{\mathrm{b}}$ & $87.04 \pm 5.47^{b}$ & $88.95 \pm 6.20^{\mathrm{b}}$ & $86.66 \pm 7.96^{\mathrm{ab}}$ & $89.38 \pm 7.16^{\mathrm{b}}$ & $93.17 \pm 6.94^{\mathrm{b}}$ & 0.0194 \\
\hline & 15 & $114.81 \pm 7.09^{\mathrm{a}}$ & $120.21 \pm 10.56^{\mathrm{b}}$ & $113.00 \pm 10.96^{\mathrm{a}}$ & $112.59 \pm 8.82^{\mathrm{a}}$ & $115.03 \pm 12.02^{\mathrm{a}}$ & $121.2 \pm 10.03^{\mathrm{b}}$ & $117.04 \pm 14.98^{\mathrm{ab}}$ & 0.0458 \\
\hline Average & & $83.04 \pm 30.36^{\mathrm{a}}$ & $88.84 \pm 31.78^{b}$ & $86.21 \pm 33.21^{\mathrm{ab}}$ & $86.54 \pm 29.33^{\mathrm{ab}}$ & $85.34 \pm 30.37^{\mathrm{ab}}$ & $88.59 \pm 33.01^{\mathrm{b}}$ & $88.43 \pm 31.21^{\mathrm{b}}$ & 0.0223 \\
\hline \multirow{3}{*}{$\begin{array}{l}\text { Bursa of } \\
\text { fabricius } \\
\text { (g) }\end{array}$} & 5 & $0.13 \pm 0.05^{\mathrm{a}}$ & $0.16 \pm 0.05^{\mathrm{b}}$ & $0.12 \pm 0.04^{\mathrm{a}}$ & $0.14 \pm 0.02^{\mathrm{a}}$ & $0.15 \pm 0.02^{\mathrm{ab}}$ & $0.15 \pm 0.02^{\mathrm{ab}}$ & $0.18 \pm 0.05^{\mathrm{b}}$ & 0.0445 \\
\hline & 10 & $0.33 \pm 0.05^{\mathrm{a}}$ & $0.40 \pm 0.06^{\mathrm{b}}$ & $0.35 \pm 0.06^{\mathrm{a}}$ & $0.38 \pm 0.09^{\mathrm{ab}}$ & $0.36 \pm 0.06^{\mathrm{ab}}$ & $0.42 \pm 0.14^{\mathrm{b}}$ & $0.37 \pm 0.11^{\mathrm{ab}}$ & 0.0316 \\
\hline & 15 & $0.58 \pm 0.12^{\mathrm{a}}$ & $0.67 \pm 0.17^{\mathrm{b}}$ & $0.60 \pm 0.15^{\mathrm{ab}}$ & $0.62 \pm 0.18^{\mathrm{ab}}$ & $0.59 \pm 0.10^{\mathrm{a}}$ & $0.58 \pm 0.13^{\mathrm{a}}$ & $0.63 \pm 0.16^{\mathrm{ab}}$ & 0.0461 \\
\hline Average & & $0.25 \pm 0.23^{\mathrm{a}}$ & $0.41 \pm 0.25^{\mathrm{b}}$ & $0.36 \pm 0.24^{\mathrm{ab}}$ & $0.36 \pm 0.25^{\mathrm{ab}}$ & $0.37 \pm 0.22^{\mathrm{ab}}$ & $0.38 \pm 0.21^{\mathrm{ab}}$ & $0.39 \pm 0.22^{\mathrm{b}}$ & 0.0381 \\
\hline \multirow{3}{*}{$\begin{array}{l}\text { Proventriculus } \\
\text { (g) }\end{array}$} & 5 & $0.78 \pm 0.15$ & $0.75 \pm 0.15$ & $0.77 \pm 0.11$ & $0.78 \pm 0.07$ & $0.78 \pm 0.11$ & $0.72 \pm 0.10$ & $0.78 \pm 0.08$ & 0.0564 \\
\hline & 10 & $0.91 \pm 0.13^{\mathrm{a}}$ & $1.13 \pm 0.15^{\mathrm{b}}$ & $1.08 \pm 0.07^{\mathrm{b}}$ & $1.02 \pm 0.08^{\mathrm{ab}}$ & $1.06 \pm 0.12^{\mathrm{ab}}$ & $1.07 \pm 0.09^{\mathrm{ab}}$ & $1.05 \pm 0.13^{\mathrm{ab}}$ & 0.0264 \\
\hline & 15 & $1.21 \pm 0.13^{\mathrm{ab}}$ & $1.21 \pm 0.15^{\mathrm{ab}}$ & $1.18 \pm 0.11^{\mathrm{a}}$ & $1.27 \pm 0.15^{\mathrm{ab}}$ & $1.22 \pm 0.15^{\mathrm{ab}}$ & $1.29 \pm 0.14^{\mathrm{b}}$ & $1.26 \pm 0.21^{\mathrm{ab}}$ & 0.0479 \\
\hline Average & & $0.97 \pm 0.22^{\mathrm{a}}$ & $1.03 \pm 0.25^{\mathrm{b}}$ & $1.01 \pm 0.21^{\mathrm{ab}}$ & $1.02 \pm 0.25^{\mathrm{ab}}$ & $1.02 \pm 0.22^{\mathrm{ab}}$ & $1.03 \pm 0.29^{\mathrm{ab}}$ & $1.03 \pm 0.24^{\mathrm{ab}}$ & 0.0416 \\
\hline \multirow{3}{*}{$\begin{array}{l}\text { Gizzard } \\
(\mathrm{g})\end{array}$} & 5 & $3.30 \pm 0.67$ & $3.27 \pm 0.77$ & $3.16 \pm 0.40$ & 3. $45 \pm 0.22$ & $3.34 \pm 0.32$ & $3.22 \pm 0.35$ & $3.37 \pm 0.66$ & 0.0691 \\
\hline & 10 & $3.94 \pm 0.44^{\mathrm{a}}$ & $4.25 \pm 0.27^{\mathrm{ab}}$ & $4.32 \pm 0.25^{\mathrm{b}}$ & $4.37 \pm 0.29^{\mathrm{b}}$ & $4.23 \pm 0.36^{\mathrm{ab}}$ & $4.39 \pm 0.50^{\mathrm{b}}$ & $4.43 \pm 0.41^{\mathrm{b}}$ & 0.0192 \\
\hline & 15 & $5.00 \pm 0.52^{\mathrm{a}}$ & $5.41 \pm 0.50^{\mathrm{b}}$ & $5.32 \pm 0.43^{\mathrm{ab}}$ & $5.15 \pm 0.52^{\mathrm{ab}}$ & $5.10 \pm 0.34^{\mathrm{ab}}$ & $5.17 \pm 0.40^{\mathrm{ab}}$ & $4.93 \pm 0.67^{\mathrm{a}}$ & 0.0002 \\
\hline Average & & $4.08 \pm 0.86^{\mathrm{a}}$ & $4.31 \pm 1.07^{\mathrm{b}}$ & $4.27 \pm 1.08^{\mathrm{b}}$ & $4.32 \pm 0.85^{\mathrm{b}}$ & $4.22 \pm 0.88^{\mathrm{b}}$ & $4.26 \pm 0.98^{\mathrm{b}}$ & $4.24 \pm 0.80^{\mathrm{b}}$ & 0.0406 \\
\hline \multirow{3}{*}{$\begin{array}{l}\text { Gut } \\
(\mathrm{cm})\end{array}$} & 5 & $50.71 \pm 4.79^{\mathrm{a}}$ & $55.50 \pm 5.78^{\mathrm{b}}$ & $54.17 \pm 6.22^{\mathrm{ab}}$ & $56.00 \pm 6.25^{\mathrm{b}}$ & $54.58 \pm 4.14^{\mathrm{ab}}$ & $51.40 \pm 3.23^{\mathrm{a}}$ & $55.12 \pm 3.29^{b}$ & 0.0317 \\
\hline & 10 & $67.10 \pm 6.42^{\mathrm{a}}$ & $71.88 \pm 5.27^{\mathrm{b}}$ & $71.11 \pm 3.26^{\mathrm{b}}$ & $70.61 \pm 5.30^{\mathrm{ab}}$ & $72.20 \pm 4.64^{\mathrm{b}}$ & $68.75 \pm 2.98^{\mathrm{ab}}$ & $66.52 \pm 6.40^{\mathrm{a}}$ & 0.0295 \\
\hline & 15 & $78.50 \pm 4.58^{\mathrm{a}}$ & $78.13 \pm 3.97^{\mathrm{b}}$ & $74.02 \pm 3.36^{\mathrm{a}}$ & $74.80 \pm 3.17^{\mathrm{a}}$ & $75.30 \pm 3.54^{\mathrm{ab}}$ & $77.60 \pm 3.66^{\mathrm{ab}}$ & $78.01 \pm 5.39^{\mathrm{b}}$ & 0.0248 \\
\hline Average & & $65.44 \pm 13.97^{\mathrm{a}}$ & $68.50 \pm 11.69^{b}$ & $66.50 \pm 10.79^{\mathrm{ab}}$ & $67.14 \pm 9.87^{\mathrm{ab}}$ & $67.36 \pm 11.18^{\mathrm{ab}}$ & $65.92 \pm 13.33^{\mathrm{ab}}$ & $66.58 \pm 11.49^{\mathrm{ab}}$ & 0.0287 \\
\hline
\end{tabular}

${ }^{\mathrm{ab}}$ Means bearing different superscripts in a row differ significantly $(\mathrm{p}<0.05) ; \mathrm{n}=10$.

of $93.0 \mathrm{~N}$ and the spindle at $100 \mathrm{rpm}$ at a temperature of $37^{\circ} \mathrm{C}$

\section{Statistical analysis}

Data are presented as means \pm SEMs. All microbiological concentrations were subjected to base-10 logarithmic transformation before analysis. Data were analyzed with SPSS13.0 software (SPSS Inc., Chicago, IL, USA) with a $1+2 \times 2$ factorial arrangement using orthogonal contrasts. Two-way analysis of variance (ANOVA) was used to analyze the means, and the Student-Newman-Keuls test was used to detect differences among means. Statistical significance was defined as $\mathrm{p}<0.05$.

\section{RESULTS}

Results of the dietary treatments on chick growth and organ development are presented in Table 2. From d 5 to 15, the body weight, and weights of the bursa, proventriculus, gizzard, and gut length increased gradually in both the control and the dietary treatment groups. When compared to the control group, the 3-d averages of the body weight, and the weights of the bursa of Fabricius, proventriculus, and gizzard, and gut length in the WSP50 group were all higher than in the control group $(\mathrm{p}<0.05)$, and there were no significant differences between the 3 -d averages in the WSP100, AEP50, and AEP100 groups compared to the control group. The 3-d averages of the body weight, and the weights of the bursa of Fabricius and gizzard in the Xase6 group were higher than those in the control group $(\mathrm{p}<0.05)$ and showed no significant difference with those in the WSP50 group. No significant difference in growth or organ development was observed among the groups treated with WSP, AEP, and xylanase when analyzing the 3-d averages. WSP100 increased weight gain and enhanced organ development (proventriculus, gizzard, and gut) on d 10 $(p<0.05)$. There was no interaction between the type of pentosan (WSP and AEP) and the dosage of pentosan (50 and $100 \mathrm{mg} / \mathrm{kg}$ ) on the body weight, and the weights of the bursa of Fabricius, proventriculus, and gizzard, and gut length $(\mathrm{p}>0.05)$.

Table 3 shows the effect of dietary treatments on digesta viscosity. In comparison to the control group, addition of WSP50, WSP100, AEP50 and AEP100 to the diet slightly increased the digesta viscosity in the ileum, cecum, and rectum from d 5 to 15 , but no significant differences in digesta viscosities were found between the WSP and AEP groups and the control group. To some extent, the inclusion of xylanase in the diet decreased intestinal digesta viscosities. Addition of Xase 3 and Xase 6 to the diet slightly lowered the digesta viscosity of the ileum, cecum, and rectum from d 5 to 15 , but no significant differences in digesta viscosities were found between the Xase 3 and Xase6 groups and the control group. The Xase3 group had significantly lower digesta viscosities at ileum when compared to the AEP50 and AEP100 groups from d 5 to 15 $(p<0.05)$. There was no interaction between the type of pentosan (WSP and AEP) and the dosage of pentosan (50 and $100 \mathrm{mg} / \mathrm{kg}$ ) on the digesta viscosity of the ileum, cecum, and rectum $(\mathrm{p}>0.05)$. 
Table 3. Effects of pentosan and xylanase on digesta viscosity in the gut $(\mathrm{Pa} \cdot \mathrm{s})$

\begin{tabular}{lccccccccc}
\hline & Days & Control & WSP50 & WSP100 & AEP50 & AEP100 & Xase3 & Xase6 & p \\
\hline Ileum & 5 & $2.04 \pm 0.21^{\mathrm{ab}}$ & $2.14 \pm 0.16^{\mathrm{ab}}$ & $2.23 \pm 0.10^{\mathrm{b}}$ & $2.26 \pm 0.17^{\mathrm{b}}$ & $2.29 \pm 0.14^{\mathrm{b}}$ & $2.01 \pm 0.17^{\mathrm{a}}$ & $1.96 \pm 0.13^{\mathrm{a}}$ & 0.0317 \\
& 10 & $1.92 \pm 0.14^{\mathrm{ab}}$ & $1.96 \pm 0.13^{\mathrm{ab}}$ & $1.99 \pm 0.13^{\mathrm{ab}}$ & $2.15 \pm 0.09^{\mathrm{b}}$ & $2.14 \pm 0.09^{\mathrm{b}}$ & $1.89 \pm 0.09^{\mathrm{a}}$ & $1.88 \pm 0.11^{\mathrm{a}}$ & 0.0019 \\
& 15 & $1.83 \pm 0.06^{\mathrm{ab}}$ & $1.93 \pm 0.08^{\mathrm{b}}$ & $1.91 \pm 0.04^{\mathrm{b}}$ & $1.96 \pm 0.05^{\mathrm{b}}$ & $2.02 \pm 0.06^{\mathrm{b}}$ & $1.73 \pm 0.07^{\mathrm{a}}$ & $1.82 \pm 0.05^{\mathrm{ab}}$ & 0.0005 \\
Cecum & 5 & $2.24 \pm 0.12^{\mathrm{ab}}$ & $2.35 \pm 0.13^{\mathrm{b}}$ & $2.33 \pm 0.16^{\mathrm{b}}$ & $2.43 \pm 0.15^{\mathrm{b}}$ & $2.51 \pm 0.16^{\mathrm{b}}$ & $2.27 \pm 0.13^{\mathrm{a}}$ & $2.21 \pm 0.13^{\mathrm{a}}$ & 0.0364 \\
& 10 & $2.19 \pm 0.14^{\mathrm{ab}}$ & $2.20 \pm 0.13^{\mathrm{ab}}$ & $2.23 \pm 0.07^{\mathrm{ab}}$ & $2.25 \pm 0.15^{\mathrm{ab}}$ & $2.28 \pm 0.13^{\mathrm{b}}$ & $2.15 \pm 0.11^{\mathrm{ab}}$ & $2.06 \pm 0.10^{\mathrm{b}}$ & 0.0283 \\
& 15 & $2.06 \pm 0.10^{\mathrm{ab}}$ & $2.11 \pm 0.12^{\mathrm{b}}$ & $2.11 \pm 0.09^{\mathrm{b}}$ & $2.12 \pm 0.14^{\mathrm{b}}$ & $2.07 \pm 0.14^{\mathrm{ab}}$ & $1.89 \pm 0.12^{\mathrm{a}}$ & $1.93 \pm 0.08^{\mathrm{ab}}$ & 0.0001 \\
Rectum & 5 & $2.08 \pm 0.16^{\mathrm{ab}}$ & $2.16 \pm 0.09^{\mathrm{b}}$ & $2.18 \pm 0.11^{\mathrm{b}}$ & $2.26 \pm 0.08^{\mathrm{b}}$ & $2.27 \pm 0.20^{\mathrm{b}}$ & $2.06 \pm 0.09^{\mathrm{ab}}$ & $1.98 \pm 0.10^{\mathrm{a}}$ & 0.0073 \\
& 10 & $1.95 \pm 0.13^{\mathrm{ab}}$ & $2.04 \pm 0.14^{\mathrm{b}}$ & $2.04 \pm 0.10^{\mathrm{b}}$ & $2.07 \pm 0.12^{\mathrm{b}}$ & $2.08 \pm 0.08^{\mathrm{b}}$ & $1.87 \pm 0.14^{\mathrm{ab}}$ & $1.83 \pm 0.13^{\mathrm{a}}$ & 0.0009 \\
& 15 & $1.95 \pm 0.13^{\mathrm{ab}}$ & $2.04 \pm 0.14^{\mathrm{b}}$ & $2.04 \pm 0.10^{\mathrm{b}}$ & $1.98 \pm 0.12^{\mathrm{b}}$ & $2.02 \pm 0.06^{\mathrm{b}}$ & $1.79 \pm 0.06^{\mathrm{ab}}$ & $1.75 \pm 0.14^{\mathrm{a}}$ & 0.0001 \\
\hline
\end{tabular}

${ }^{\mathrm{ab}}$ Means bearing different superscripts in a row differ significantly $(\mathrm{p}<0.05) ; \mathrm{n}=5$.

Table 4 shows the effects of the dietary treatments on the concentrations of bacterial strains in the rectum. The Lactobacillus concentrations in the WSP50, Xase3, and Xase6 groups were significantly increased compared with the control group $(\mathrm{p}<0.05)$ and were slightly higher than in the WSP100, AEP50, and AEP100 groups. However, the WSP50 group had the lowest levels of Streptococcus and $E$. coli among all of the groups. There was no interaction between the type of pentosan (WSP and AEP) and the dosage of pentosan $(50$ and $100 \mathrm{mg} / \mathrm{kg})$ on the Lactobacillus, Streptococcus, and E. coli concentrations.

The results concerning the effects of WSP, AEP, and xylanase on the $\mathrm{pH}$ of the gut digesta are presented in Table 5. The $\mathrm{pH}$ levels throughout the gut in all of the dietary treatment groups were slightly lower than that of the control group, with significant differences detected between the Xase 3 and control groups in the ileum and cecum on $\mathrm{d} 10$ and $15(\mathrm{p}<0.05)$. There was no interaction between the type of pentosan (WSP and AEP) and the dosage of pentosan (50 and $100 \mathrm{mg} / \mathrm{kg}$ ) on the $\mathrm{pH}$ of the ileum, cecum, and rectum.

\section{DISCUSSION}

Dietary fiber, known as "crude fiber", was overlooked

Table 4. Effects of pentosans and xylanase on the microflora in the gut $(\log 10 \mathrm{cfu} / \mathrm{g})$

\begin{tabular}{lccccccccc}
\hline & Days & Control & WSP50 & WSP100 & AEP50 & AEP100 & Xase3 & Xase6 & p \\
\hline Lactobacillus & 5 & $4.38 \pm 0.16^{\mathrm{a}}$ & $4.61 \pm 0.16^{\mathrm{b}}$ & $4.47 \pm 0.17^{\mathrm{b}}$ & $4.46 \pm 0.16^{\mathrm{b}}$ & $4.53 \pm 0.15^{\mathrm{b}}$ & $4.47 \pm 0.17^{\mathrm{b}}$ & $4.49 \pm 0.12^{\mathrm{b}}$ & 0.0078 \\
& 10 & $4.54 \pm 0.16^{\mathrm{a}}$ & $4.73 \pm 0.15^{\mathrm{b}}$ & $4.66 \pm 0.16^{\mathrm{ab}}$ & $4.70 \pm 0.16^{\mathrm{b}}$ & $4.62 \pm 0.17^{\mathrm{ab}}$ & $4.77 \pm 0.15^{\mathrm{b}}$ & $4.78 \pm 0.15^{\mathrm{b}}$ & 0.0286 \\
& 15 & $4.85 \pm 0.15^{\mathrm{a}}$ & $5.01 \pm 0.15^{\mathrm{b}}$ & $5.02 \pm 0.16^{\mathrm{b}}$ & $5.11 \pm 0.16^{\mathrm{b}}$ & $5.06 \pm 0.17^{\mathrm{b}}$ & $5.22 \pm 0.15^{\mathrm{b}}$ & $5.25 \pm 0.15^{\mathrm{b}}$ & 0.0291 \\
Streptococcus & 5 & $3.84 \pm 0.16^{\mathrm{a}}$ & $3.64 \pm 0.17^{\mathrm{b}}$ & $3.73 \pm 0.14^{\mathrm{ab}}$ & $3.76 \pm 0.14^{\mathrm{ab}}$ & $3.73 \pm 0.14^{\mathrm{ab}}$ & $3.87 \pm 0.15^{\mathrm{a}}$ & $3.78 \pm 0.15^{\mathrm{a}}$ & 0.0462 \\
& 10 & $4.30 \pm 0.16$ & $4.28 \pm 0.16$ & $4.65 \pm 0.15$ & $4.52 \pm 0.15$ & $4.60 \pm 0.15$ & $4.76 \pm 0.15$ & $4.62 \pm 0.15$ & 0.0513 \\
& 15 & $4.78 \pm 0.16$ & $4.50 \pm 0.16$ & $4.89 \pm 0.15$ & $5.01 \pm 0.15$ & $5.06 \pm 0.16$ & $5.18 \pm 0.15$ & $5.08 \pm 0.14$ & 0.0549 \\
E. coli & 5 & $3.86 \pm 0.15^{\mathrm{ab}}$ & $3.56 \pm 0.14^{\mathrm{a}}$ & $3.86 \pm 0.14^{\mathrm{ab}}$ & $3.73 \pm 0.14^{\mathrm{ab}}$ & $3.96 \pm 0.14^{\mathrm{b}}$ & $4.26 \pm 0.15^{\mathrm{b}}$ & $4.33 \pm 0.14^{\mathrm{b}}$ & 0.0371 \\
& 10 & $4.89 \pm 0.14^{\mathrm{ab}}$ & $4.63 \pm 0.14^{\mathrm{a}}$ & $5.05 \pm 0.15^{\mathrm{b}}$ & $4.79 \pm 0.14^{\mathrm{ab}}$ & $5.05 \pm 0.14^{\mathrm{b}}$ & $4.88 \pm 0.16^{\mathrm{ab}}$ & $4.72 \pm 0.16^{\mathrm{ab}}$ & 0.0388 \\
& 15 & $5.34 \pm 0.15$ & $5.09 \pm 0.15$ & $5.30 \pm 0.16$ & $5.23 \pm 0.16$ & $5.50 \pm 0.15$ & $5.54 \pm 0.15$ & $5.49 \pm 0.15$ & 0.0601 \\
\hline
\end{tabular}

${ }^{\mathrm{ab}}$ Means bearing different superscripts in a row differ significantly $(\mathrm{p}<0.05) ; \mathrm{n}=5$.

Table 5. Effects of pentosans and xylanase on the chime $\mathrm{pH}$ in the gut

\begin{tabular}{llllllllll}
\hline & Days & Control & WSP50 & WSP100 & AEP50 & AEP100 & Xase3 & Xase6 & p \\
\hline Ileum & 5 & $7.08 \pm 0.05$ & $6.94 \pm 0.06$ & $6.99 \pm 0.03$ & $6.92 \pm 0.02$ & $6.98 \pm 0.06$ & $6.78 \pm 0.07$ & $6.90 \pm 0.06$ & 0.0537 \\
& 10 & $6.91 \pm 0.06^{\mathrm{a}}$ & $6.81 \pm 0.08^{\mathrm{ab}}$ & $6.78 \pm 0.13^{\mathrm{ab}}$ & $6.90 \pm 0.06^{\mathrm{a}}$ & $6.76 \pm 0.03^{\mathrm{ab}}$ & $6.63 \pm 0.05^{\mathrm{b}}$ & $6.82 \pm 0.04^{\mathrm{ab}}$ & 0.0446 \\
& 15 & $6.84 \pm 0.06^{\mathrm{a}}$ & $6.76 \pm 0.06^{\mathrm{ab}}$ & $6.69 \pm 0.05^{\mathrm{ab}}$ & $6.80 \pm 0.08^{\mathrm{a}}$ & $6.68 \pm 0.04^{\mathrm{ab}}$ & $6.61 \pm 0.03^{\mathrm{b}}$ & $6.68 \pm 0.03^{\mathrm{ab}}$ & 0.0467 \\
Cecum & 5 & $6.92 \pm 0.14^{\mathrm{ab}}$ & $6.91 \pm 0.08^{\mathrm{ab}}$ & $6.98 \pm 0.07^{\mathrm{a}}$ & $6.95 \pm 0.05^{\mathrm{a}}$ & $6.80 \pm 0.06^{\mathrm{ab}}$ & $6.70 \pm 0.04^{\mathrm{b}}$ & $6.86 \pm 0.09^{\mathrm{ab}}$ & 0.0403 \\
& 10 & $6.88 \pm 0.08^{\mathrm{a}}$ & $6.75 \pm 0.09^{\mathrm{ab}}$ & $6.80 \pm 0.13^{\mathrm{ab}}$ & $6.79 \pm 0.14^{\mathrm{ab}}$ & $6.71 \pm 0.07^{\mathrm{b}}$ & $6.66 \pm 0.05^{\mathrm{b}}$ & $6.73 \pm 0.06^{\mathrm{ab}}$ & 0.0384 \\
& 15 & $6.80 \pm 0.09^{\mathrm{a}}$ & $6.72 \pm 0.05^{\mathrm{ab}}$ & $6.74 \pm 0.04^{\mathrm{ab}}$ & $6.73 \pm 0.02^{\mathrm{ab}}$ & $6.55 \pm 0.07^{\mathrm{ab}}$ & $6.47 \pm 0.08^{\mathrm{b}}$ & $6.61 \pm 0.08^{\mathrm{ab}}$ & 0.0399 \\
Rectum & 5 & $7.13 \pm 0.06$ & $7.10 \pm 0.02$ & $7.11 \pm 0.09$ & $7.08 \pm 0.02$ & $6.92 \pm 0.02$ & $6.99 \pm 0.09$ & $6.92 \pm 0.10$ & 0.0528 \\
& 10 & $7.08 \pm 0.16$ & $6.91 \pm 0.09$ & $6.97 \pm 0.12$ & $6.99 \pm 0.16$ & $6.67 \pm 0.03$ & $6.84 \pm 0.12$ & $6.85 \pm 0.09$ & 0.0591 \\
& 15 & $6.86 \pm 0.15^{\mathrm{a}}$ & $6.87 \pm 0.07^{\mathrm{a}}$ & $6.83 \pm 0.05^{\mathrm{a}}$ & $6.84 \pm 0.07^{\mathrm{a}}$ & $6.65 \pm 0.03^{\mathrm{b}}$ & $6.77 \pm 0.10^{\mathrm{ab}}$ & $6.81 \pm 0.06^{\mathrm{b}}$ & 0.0472 \\
\hline
\end{tabular}

${ }^{\mathrm{ab}}$ Means bearing different superscripts in a row differ significantly $(\mathrm{p}<0.05) ; \mathrm{n}=5$. 
until the 1970s. Today, dietary fiber is considered "the seventh largest nutrient for humans", and its importance is increasingly being recognized. Many studies have revealed that low dietary fiber intake is associated with a variety of human diseases, such as colon cancer and diabetes. Dietary fibers are often supplemented as prebiotics in modern society (Park et al., 2007).

Typically, dietary fiber decreases intestinal transit time, adds bulk to the stool, and promotes colonic fermentation in humans. There have been relatively few reports on the physiological functions and appropriate dosage of pentosans as dietary fiber. The limited data available are mostly on the anti-nutritive effect of pentosans in the animal feed industry. In this study, we found that WSP supplementation at $50 \mathrm{mg} / \mathrm{kg}$ diet promoted weight gain and organ development of broiler chicks fed corn-soybean meal-based diets, suggesting that pentosans may act as physiological enhancers and promote the growth of broiler chicks. Our finding is consistent with that of Courtin et al. (2008). In their study, supplementing $0.5 \%$ rice bran arabinoxylan to a wheat-based diet and $0.25 \%$ rice bran arabinoxylan to a corn-based diet improved the food conversion rate, and this beneficial effect was attributed to the prebiotic properties of arabinoxylan. Our result differs from that of Choct et al. (1990) who reported an antinutritive effect of pentosans. The discrepancy may due to the different levels of WSP and AEP in the test diets. A minimum of $4.8 \mathrm{~g} / \mathrm{kg}$ DM WSP or $3.5 \mathrm{~g} / \mathrm{kg}$ DM WIP was added to sorghum-casein hydrochloride based diets in the study by Choct et al. (1990). In the present study, a cornsoybean meal-based diet was used and the maximal level of WSP and AEP supplementation was $100 \mathrm{mg} / \mathrm{kg}$. It is possible that pentosans function as prebiotics at 50 and 100 $\mathrm{mg} / \mathrm{kg}$ supplementation in this study but as an anti-nutritive factor when supplemented at higher levels. Furthermore, the varying effects may be partially due to the different types of basal diets (sorghum-casein vs corn-soybean). In another study (Choct et al., 1992), dietary supplementation of AEP at $35 \mathrm{~g} / \mathrm{kg}$ diet increased digesta viscosity in the ileum by twofold and depressed broiler performance. In the present study, inclusion of AEP at $100 \mathrm{mg} / \mathrm{kg}$ in the diet had no influence on the viscosity of the intestinal digesta and growth performance. The large difference between including $35 \mathrm{~g} / \mathrm{kg}$ and $100 \mathrm{mg} / \mathrm{kg}$ of AEP in the diet may explain the conflicting results in digesta viscosity and growth performance observed in the two independent studies. Digesta viscosity is known to have an antinutritional effect (Choct et al., 1990). No data are available regarding to the range of changes in digesta viscosity following the inclusion of AEP in the diet of broiler chicks.

We found that dietary supplementation of $50 \mathrm{mg} / \mathrm{kg}$ WSP promoted the growth performance and organ development of broiler chicks in the present study. In contrast, supplementation of $100 \mathrm{mg} / \mathrm{kg} \mathrm{WSP}$, and $50 \mathrm{mg} / \mathrm{kg}$ or $100 \mathrm{mg} / \mathrm{kg}$ AEP had little or no effect. These findings suggest that WSP and AEP differ in their function and effective dosages. Studies comparing the functional effects of low levels of WSP and AEP are limited. Furthermore, the different basal diets and various levels of fiber contained in the basal diets are often confounding factors when evaluating the effect of WSP or AEP per se. JiménezMoreno et al. (2010) demonstrated that the addition of 30 $\mathrm{g} / \mathrm{kg}$ oat hull improved gizzard weight and growth performance in young chicks fed low-fiber diets $(15.4 \mathrm{~g} / \mathrm{kg})$. It is estimated that the low-fiber diet in their study with 20 and $30 \mathrm{~g} / \mathrm{kg}$ oat hull supplementation (Mateos et al., 2012) contained a total of 94 and $141 \mathrm{mg} / \mathrm{kg}$ WSP and 2,044 and $3,066 \mathrm{mg} / \mathrm{kg}$ pentosans based on the data of Hashimoto et al. (1987). In the present study, the exogenous WSP was 50 and $100 \mathrm{mg} / \mathrm{kg}$ and the dietary fiber was $26.0 \mathrm{~g} / \mathrm{kg}$. The WSP levels in the two studies were at comparable levels, but the other dietary fiber compositions were different; therefore, the beneficial effects of prebiotic function in the study by Jiménez-Moreno et al. (2010) may not be simply due to the WSP in the oat hull. Similarly, the function and effective dosage of AEP could also be affected by the type of basal diet and other dietary fiber components in different studies (González-Alvarado et al., 2008; Jiménez-Moreno et al., 2010; Mateos et al., 2012; Rochell et al., 2012). To our knowledge, this is the first report that directly compares the effects of WSP and AEP supplementation on animal growth performance at practical levels.

The differences in the physiological responses and functions of WSP and AEP may be partially explained by the structural diversities of the arabinoxylans. Damen et al. (2011) showed that the prebiotic effects and enteric fermentation of arabinoxylans are structure-dependent. It has also been reported that intestinal flora are highly selective for the structures of pentosans (Moura et al., 2008). As a result of this selectivity, pentosans of various structures display different prebiotic effects and enteric fermentation capacities (Moura et al., 2008; Van Craeyveld et al., 2008). The observation in this study that only WSP50 increased the concentration of Lactobacillus in the rectum may be explained by this selectivity.

Numerous studies have reported the effects of xylanase on the growth performance of broiler chicks. The reduction of digesta viscosity by xylanase has been proposed as the underlying mechanism for the improvements in digestion and growth performance (Redgwell et al., 2001; Murphy et al., 2009). However, this theory is still under intensive debate. Dusel et al. (1998) suggested that xylanase enhances the performance of broiler chicks by improving the digestibility of dietary starch and fat, and the reduction in digesta viscosity may be the result of improved digestibility. Mathlouthi et al. (2002) speculated that xylanase improves 
animal growth performance by modifying the conjugated bile acids in the intestinal content. Bao et al. (2010) reported that xylanase can hydrolyze non-starch polysaccharides and generate more phenolic resin, which act as anti-oxidants and clear the free radicals in the gut. In the present study, supplementation of xylanase reduced the digesta viscosity in the rectum of broiler chicks when compared to AEP supplementation. This result is supported by data from an in vitro study conducted by Rumpaqaporn et al. (2012) in which alkali-extractable arabinoxylan solution showed higher viscosity than xylanase-hydrolyzate. Although the decrease in digesta viscosity with xylanase supplementation was not significant in the present study when compared to the control group, the reduction could have a positive influence on food digestion and nutrient absorption. The lack of a significant change in digesta viscosity with WSP and AEP supplementation is likely due to the low dosages in the present study. The influence of these low dosages of WSP and AEP on the microflora concentration could be minimal as well. We only observed an increase in the Lactobacillus concentration in the rectum with $50 \mathrm{mg} / \mathrm{kg}$ WSP supplementation.

Inclusion of xylanase in the diet, particularly at the 3 $\mathrm{mg} / \mathrm{kg}$ level, increased the concentration of Lactobacillus in the rectum and lowered the $\mathrm{pH}$ in the ileum on $\mathrm{d} 10$ and 15 $(\mathrm{p}<0.05)$. WSP and AEP are the products of the hydrolysis of $\alpha$-amylase and the breakdown of the $\alpha-1,4$-glycosidic bond, whereas xylanase hydrolyzes the $\beta-1$, 4-glycosidic bond of polysaccharides. Therefore, xylanase activity will generate products different from WSP and AEP. Apparently, products generated from xylanase activity are substrates for Lactobacillus. As a result, xylanase promoted microflora proliferation and fermentation, reduced gut $\mathrm{pH}$, and enhanced food digestion and absorption.

\section{CONCLUSION}

Supplementation of WSP and xylanase in a cornsoybean meal-based diet improved the growth performance of broiler chicks, with supplementation of WSP at $50 \mathrm{mg} / \mathrm{kg}$ diet being the most efficient in promoting organ development. Both WSP and xylanase increased the concentration of gut Lactobacillus. WSP tended to increase digesta viscosity, whereas xylanase tended to reduce digesta viscosity in the gut. The mechanisms by which WSP and xylanase supplementation improved growth in the broiler chicks fed a corn-soybean based diet may differ. The results of this study suggest that inclusion of a low level of WSP in animal feed may provide beneficial prebiotic functions and avoid the anti-nutritive effect often associated with high levels of dietary fiber. Further studies are warranted to verify the efficacy of WSP50 in animal feed and to elucidate their functional mechanisms.

\section{ACKNOWLEDGEMENTS}

The authors would like to acknowledge Medjaden Bioscience Limited for their assistance in manuscript preparation.

This project was supported by a grant from the National Natural Science Foundation of China (31172245).

\section{REFERENCES}

Anderson, J. W., A. E. Jones, and S. Riddell-Mason. 1994. Ten different dietary fibers have significantly different effects on serum and liver lipids of cholesterol-fed rats. J. Nutr. 1:78-83.

Antoniou, T. and R. R. Marquardt. 1981. Influence of rye pentosans on the growth of chicks. Poult. Sci. 60:1898-1904.

Bao, Y. M. and M. Choct. 2010. Dietary NSP nutrition and intestinal immune system for broiler chickens. World's Poult. Sci. J. 66:511-518.

Boguhn, J. and M. Rodehutscord. 2007. Effects of non-starch polysaccharide hydrolysing enzyme preparations in male and female turkeys fed wheat-based diets. Arch. Geflügelk. 4:152161.

Broekaert, W. F., C. M. Courtin, K. Verbeke, T. Van de Wiele, W. Verstraete, and J. A. Delcour. 2011. Prebiotic and other healthrelated effects of cereal-derived arabinoxylans, arabinoxylanoligosaccharides, and xylooligosaccharides. Crit. Rev. Food Sci. Nutr. 51:178-194.

Choct, M. and G. Annison. 1990. Anti-nutritive activity of wheat pentosans in broiler diets. Br. Poult Sci. 31:811-821.

Choct, M. and G. Annison. 1992. Anti-nutritive effect of wheat pentosans in broiler chickens: roles of viscosity and gut microflora. Br. Poult. Sci. 33:821-834.

Courtin, C. M., W. F. Broekaert, K. Swennen, O. Lescroart, O. Onagbesan, J. Buyse, E. Decuypere, T. V. W. U. Gent, M. M. U. Gent, W. V. U. Gent, G. Huyghebaert, and J. A. Delcour. 2008. Dietary inclusion of wheat bran arabinoxylooligosaccharides induces beneficial nutritional effects in chickens. Cereal Chem. 85: 607-613.

Damen, B., J. Verspreet, A. Pollet, W. F. Broekaert, J. A. Delcour, and C. M. Courtin. 2011. Prebiotic effects and intestinal fermentation of cereal arabinoxylans and arabinoxylan oligosaccharides in rats depend strongly on their structural properties and joint presence. Mol. Nutr. Food Res. 55:18621874.

Dusel, G., H. Kluge, H. Jeroch, and O. Simon 1998. Xylanase supplementation of wheat-based rations for broilers: influence of wheat characteristics. J. Appl. Poult. Res.7:119-131.

Duthie, G., L. Whyte, H. Chandran, S. Lawson, M. Velangi, and L. McCarthy. 2012. Introduction of sodium pentosan polysulfate and avoidance of urethral catheterisation: Improved outcomes in children with haemorrhagic cystitis post stem cell transplant/chemotherapy. J. Pediatr. Surg. 47:375-379.

François, I. E., O. Lescroart, W. S. Veraverbeke, M. Marzorati, S. Possemiers, P. Evenepoe, H. Hamer, E. Houben, K. Windey, G. W. Welling, J. A. Delcour, C. M. Courtin, K. Verbeke, and W. F. Broekaert. 2012. Effects of a wheat bran extract containing arabinoxylan oligosaccharides on gastrointestinal health parameters in healthy adult human volunteers: a double-blind, 
randomised, placebo-controlled, cross-over trial. Br. J. Nutr. 108: 2229-22242.

Ghoneum, M. and A. Jewett. 2000. Production of tumor necrosis factor-alpha and interferon-gamma from human peripheral blood lymphocytes by MGN-3, a modified arabinoxylan from rice bran, and its synergy with interleukin-2 in vitro. Cancer Detect. Prev. 24:314-324.

González-Alvarado, J. M., E. Jiménez-Moreno, D. G. Valencia, R. Lázaro, and G. G. Mateos. 2008. Effects of fiber source and heat processing of the cereal on the development and ph of the gastrointestinal tract of broilers fed diets based on corn or rice. Poult. Sci. 87:1779-1795.

Gu, M., H. Ma, K. Mai, W. Zhang, N. Bai, and X. Wang. 2011. Effects of dietary $\beta$-glucan, mannan oligosaccharide and their combinations on growth performance, immunity and resistance against Vibrio splendidus of sea cucumber, Apostichopus japonicus. Fish Shellfish Immunol. 31:303-309.

Hashimoto, S., M. D. Shogren, L. C. Bolte, and Y. Pomeranz. 1987. Cereal pentosans: their estimation and significance. III. Pentosans in abraded grains and milling by-products. Cereal Chem. 64:39-41.

Hee-Jeong, S., K. Hyung-Jun, C. Jeong-Hoon, K. Hyung-Tae, Y. Hyo-Seong, E. Su-Ju, L. Yea-Hyun, K. Hyo-Jeong, and K. Chang-Keun. 2012. Effects of arabinoxylan rice bran and exercise training on immune function and inflammation response in lipopolysaccharide-stimulated rats. J. Appl. Biol. Chem.55:41-46.

Izydorczyk, M. S. and C. G. Biliaderis. 1995. Cereal arabinoxylans: advances in structure and physicochemical properties. Carbohydr. Polym. 28:33-48.

Jiménez-Moreno, E., J. M. González-Alvarado, D. GonzálezSánchez, R. Lázaro, and G. G. Mateos. 2010. Effects of type and particle size of dietary fiber on growth performance and digestive traits of broilers from 1 to 21 days of age. Poult. Sci. 89:2197-2212.

Kabel, M. A., L. Kortenoeven, H. A. Schols, and A. G. Voragen. 2002. In vitro fermentability of differently substituted xylooligosaccharides. J. Agric. Food Chem. 50:6205-6210.

Kalmendal, R. and R. Tauson. 2012. Effects of a xylanase and protease, individually or in combination, and an ionophore coccidiostat on performance, nutrient utilization, and intestinal morphology in broiler chickens fed a wheat-soybean mealbased diet. Poult. Sci. 91:1387-1393.

Lu, Z. X., P. R. Gibson, J. G. Muir, M. Fielding, and K. O'Dea. 2000a. Arabinoxylan fiber from a by-product of wheat flour processing behaves physiologically like a soluble, fermentable fiber in the large bowel of rats. J. Nutr. 130:1984-1990.

Lu, Z. X., K. Z. Walker, J. G. Muir, T. Mascara, and K. O'Dea. 2000b. Arabinoxylan fiber, a byproduct of wheat flour processing, reduces the postprandial glucose response in normoglycemic subjects. Am. J. Clin. Nutr. 71:1123-1128.

Maki, K. C., G. R. Gibson, R. S. Dickmann, C. W. Kendall, C. Y. Chen, A. Costabile, E. M. Comelli, D. L. McKay, N. G. Almeida, D. Jenkins, G. A. Zello, and J. B. Blumberg. 2012. Digestive and physiologic effects of a wheat bran extract, arabino-xylan-oligosaccharide, in breakfast cereal. Nutrition 28:1115-1121.

Mateos, G. G., E. Jiménez-Moreno, M. P. Serrano, and R. P. Lázaro. 2012. Poultry response to high levels of dietary fiber sources varying in physical and chemical characteristics. J. Appl. Poult. Res. 21:156-174.

Mathlouthi, N., J. P. Lallès, P. Lepercq, C. Juste, and M. Larbier. 2002. Xylanase and $\beta$-glucanase supplementation improve conjugated bile acid fraction in intestinal contents and increase villus size of small intestine wall in broiler chickens fed a ryebased diet. J. Anim. Sci. 80:2773-2779.

Moura, P., S. Cabanas, P. Lourenço, F. Gírio, M. C. Loureiro-Dias, and M. P. Esteves. 2008. In vitro fermentation of selected xylooligosaccharides by piglet intestinal microbiota. LWT - Food Sci. Technol. 41:1952-1961.

Murphy, T. C., J. K. Mccracken, M. E. McCann, J. George, and M. R. Bedford. 2009. Broiler performance and in vivo viscosity as influenced by a range of xylanases, varying in ability to effect wheat in vitro viscosity. Br. Poult. Sci. 50:716-724.

Park, J. and M. H. Floch. 2007. Prebiotics, probiotics, and dietary fiber in gastrointestinal disease. Gastroenterol. Clin. North Am. 36:47-63.

Reddy, B. S., Y. Hirose, L. A. Cohen, B. Simi, I. Cooma, and C. V. Rao. 2000. Preventive potential of wheat bran fractions against experimental colon carcinogenesis: Implications for human colon cancer prevention. Cancer Res. 60:4792-4797.

Redgwell, R. J., J.-H. de Michieli, M. Fischer, S. Reymond, P. Nicolas, and D. Sievert. 2001. Xylanase Induced Changes to Water- and Alkali-Extractable Arabinoxylans in Wheat Flour: Their Role in Lowering Batter Viscosity. J. Cereal Sci. 33:8396.

Rochell, S. J., T. J. Applegate, E. J. Kim, and W. A. Dozier III. 2012. Effects of diet type and ingredient composition on rate of passage and apparent ileal amino acid digestibility in broiler chicks. Poult. Sci. 91:1647-1653.

Rumpagaporn, P., A. Kaur, O. H. Campanella, J. A. Patterson, and B. R. Hamaker. 2012. Heat and pH stability of alkaliextractable corn arabinoxylan and its xylanase-hydrolyzate and their viscosity behavior. J. Food Sci. 77:23-30.

Shashidhara, R. G. and G. Devegowda. 2003. Effect of dietary mannan oligosaccharide on broiler breeder production traits and immunity. Poult. Sci. 82:1319-1325.

Shinnick, F. L., R. Mathews, and S. Ink. 1991. Serum cholesterol reduction by oats and other fiber sources. Cereal Foods World. 36:815-821.

Sohail, M. U., A. Ijaz, M. S. Yousaf, K. Ashraf, H. Zaneb, M. Aleem, and H. Rehman. 2010. Alleviation of cyclic heat stress in broilers by dietary supplementation of mannanoligosaccharide and Lactobacillus-based probiotic: Dynamics of cortisol, thyroid hormones, cholesterol, C-reactive protein, and humoral immunity. Poult. Sci. 89:1934-1938.

Topping, D. 2007. Cereal complex carbohydrate and their contribution to human health. J. Cereal Sci. 46:220-229.

Van-Craeyveld, V., K. Swennen, E. Dornez, T. Van-de-Wiele, M. Marzorati, W. Verstraete, Y. Delaedt, O. Onagbesan, E. Decuypere, J. Buyse, B. De-Ketelaere, W. F. Broekaert, J. A. Delcour, and C. M. Courtin. 2008. Structurally different wheatderived arabinoxylooligosaccharides have different prebiotic and fermentation properties in rats. J. Nutr. 138:2348-2355.

Xue-Ling, Z., Z. Jie, and L. Li-Min. 2008. A study on effect of wheat bran pentosans on loosing the bowel to relieve constipation. Cereal Feed Ind. 8:14-16. (in Chinese). 